\title{
The Social Role of Women within the Legal and Parliamentary Context in Ecuador
}

\author{
Navarro Mercedes', Cejas Magda², Vega Vladimir³, Mendoza Derling4 \\ ${ }^{1}$ Universidad Regional Autónoma de los Andes UNIANDES, Riobamba, Ecuador \\ ${ }^{2}$ Universidad Nacional de Chimborazo UNACH and Universidad de las Fuerzas Armadas ESPE, Riobamba, Ecuador \\ ${ }^{3}$ Universidad Regional Autónoma de los Andes UNIANDES, Ambato, Ecuador \\ ${ }^{4}$ Universidad Nacional de Educación UNAE, Chuquipata, Ecuador \\ Email: magda.cejas@unach.edu.ec
}

How to cite this paper: Mercedes, N., Magda, C., Vladimir, V., \& Derling, M. (2020). The Social Role of Women within the Legal and Parliamentary Context in Ecuador. Open Journal of Social Sciences, 8 , 399-409.

https://doi.org/10.4236/jss.2020.89030

Received: August 24, 2020

Accepted: September 26, 2020

Published: September 29, 2020

Copyright $\odot 2020$ by author(s) and Scientific Research Publishing Inc. This work is licensed under the Creative Commons Attribution International License (CC BY 4.0).

http://creativecommons.org/licenses/by/4.0/

\begin{abstract}
The main objective was to analyse gender equality in the context of its social, legal and parliamentary role in Ecuador. The methodology was systematically based on the mixed model of concurrent transformative design. Documentary and statistical data were collected from major sources. The information was analysed using the triangulation method. The results were three categories. The constitutional regulation of gender equality. The legal regulation of gender equality in the parliamentary sphere. Statistical data on gender equality in the legal parliamentary sphere. In conclusion, it has been established that a more educated society is more inclusive and that erradicates female discrimination.
\end{abstract}

\section{Keywords}

Women, Equality, Social Role, Legal, Parliamentary

\section{Introduction}

Since 1975, world conferences on women have been held within the United Nations, since then, four conferences have been held, these being the following: the Mexico City conference in 1975, the Copenhagen Conference in 1980, that of Nairobi in 1985 and finally that of Beijing in 1999. Indeed, for Vela (2009) these conferences, held from 1975-1995, pointed to the search for equality between the sexes at a moment in time in that the struggle for these principles was absent from the political agendas of the States. In this sense, one of the most important objectives and/or achievements of that time as a result of the development of the debates promoted in the aforementioned-was the incorporation in legal mat- 
ters of the concept of transversality that Hook and Wolfe (2018) define as gender policies those that are focused on preventing and prohibiting any type of discrimination and in the words of the Council of Europe (1999) is the organization (reorganization), improvement, development and evaluation of political processes, so that a gender equality perspective is incorporated into all policies by the actors normally involved in the adoption of these measures. In this way, it was sought to fight for peace, security at a global, regional and local level, seeking the prevention and protection of women and girls through the incorporation of policies that would promote adequate mechanisms for the solutions of the problems that in the matter gender arose.

Therefore, once the concept of transversality was introduced into the agendas of States, gender equality began to have greater relevance in the United Nations until it became part of the Millennium Goals, especially by the ONU (2015), which has managed to improve women's conditions in both social and parliamentary life, where in the last 20 years women obtained $90 \%$ representation in 174 countries, doubling their average participation rate in the same period. However, for those who subscribe to this study in the legal sphere, women have also had their rights recognized throughout the ages, as well as constitutional guarantees, which are often not recognized in the countries.

Daniely and Lederman (2019) point out that it is necessary to continue working on the implementation of transversal measures that strengthen social spaces where women do not have any representation or their representation is limited by external factors. An example of these spaces is precisely decision-making in accordance with the situation of women in all areas of their performance (social, political, legal, labor). In a different vein, the search for gender equality has now been included in the United Nations 2030 Agenda in the Sustainable Development Goals, specifically goal number 5 expresses achieving gender equality and empowerment of the woman and the girl.

That is why the legislative measures taken in countries where events of gender discrimination are reflected must respond to the principle of material equality, that is, they must establish and also guarantee rights to vulnerable groups, which necessarily implies its materialization of the norm in the practical sphere of its application, for which Pons (2015) proposes improving a strictly symmetrical or parity meaning of equality and excluding certain favorable measures from consideration as discriminatory, also Orbegoso (2016), he cannot fail to highlight the modern conception of the Social State, where the importance of achieving material equality is stressed. The state had to change to meet the new demands of society, which conceives of itself as plural. In the light of the above, the general objective of the article is to analyse gender equality in the context of its social, legal and parliamentary role in Ecuador, based, inter alia, on the complexity of the line of research on gender, which is based on the idea of prohibiting discrimination but also establishing legal norms that guarantee and promulgate non-discrimination, always bearing in mind that this is a sensitive process that must be carried out with the greatest possible care. 


\section{Categories of Study in the Social Role of Women in Ecuador}

\subsection{Constitutional Regulation of Gender Equality in Ecuador}

In the Ecuadorian legal system, reference must be made in the first place to the CRE (2008) whose last modification was on July 13, 2011, it refers to the recognition of formal material equality and non-discrimination for all people. Specifically, the principle of equality is contemplated in Article 11.2, which establishes that "All persons are equal and shall enjoy the same rights, duties and opportunities (...) The State shall adopt affirmative action measures that promote equality real in favor of the holders of rights who are in a situation of inequality".

In another aspect, the prohibition of discrimination, contemplated in article 156 , establishes that "it is recognized and guaranteed to people: 4. Right to formal equality, material equality and non-discrimination”. In turn, Article 393 should be noted, which states that "human security will be guaranteed (...) to ensure the peaceful coexistence of people, promote a culture of peace and prevent forms of violence and discrimination (...)".

Huh (2020) affirms that in the doctrine when referring to equality and non-discrimination, these principles are related to the basis of constitutional States and therefore all people are born free and equal in dignity and rights, and that therefore We should not be subjected to arbitrarily differentiated treatments which require criteria to be identified as "arbitrary".

These two normative provisions are a mandate of the supreme norm in order to channel the conduct of public powers towards the execution of legal measures that are responsible for regulating equality in all senses. One of these measures is also the creation of International Labour Organization (2016), where it is established in article 156 that they will be bodies "responsible for ensuring the full validity and exercise of the rights enshrined in the Constitution and in international human rights instruments".

In a second approach, the constitutional norm of the CRE (2008) also contemplates in article 88 the so-called protection action or "the direct and effective protection of the rights recognized in the Constitution" and that can be filed by a person Who feels like a victim can also be interposed by a person, who, as a victim and according to the aforementioned article, considers that there was a violation of constitutional rights, within which the supreme rule emphasizes 3 specific situations: subordination, defenselessness or discrimination that would be the factor in our case study. As determined in the aforementioned context, although this mechanism does not constitute by itself a satisfactory or sufficient response to make it effective and adequate, it will depend on factors such as: legal practice, political will and concrete or abstract control of the Constitution that is exercised by the Constitutional Court, which is binding and must go hand in hand with the legal regulation that has been developed in Ecuador through legal regulations on this matter. 


\subsection{Legal Regulation around the Equality of Gender in the Parliamentary Sphere in Ecuador}

In the Republic of Ecuador, the Organic Law of the Council of Citizen Participation and Social Control of September 22, 2009, being the last modification of November 24, 2014, makes mention of the principles that correspond to its actions, indicating equality and the focus of gender. Article 19 should highlight the reference they make to the need to guarantee alternate parity between men and women, while in Article 2 it refers to the search to guarantee equality in all aspects of social and public life in the Ecuadorian State. In another aspect, the Organic Law of the Public Service Supplement number 294 of October 6, 2010, indicates the importance of having parity between men and women in the processes of selection and incorporation into the public service and also in those positions that are nominated and designation according to article 5. These last two precepts can also be related to the Organic Law on Electoral and Political Organizations (2009), the Code of Democracy whose official Ecuadorian Registry is supplement 587 of February 6, 2012 and where parity and alternation between male or female candidates in the electoral field within the principles that govern this system.

Thus, Article 3 indicates that the State must promote the equal participation of women and men in nomination or appointment positions, in all instances of public function, in those of direction and decision-making and within political parties, not to mention the obligation for women to participate in candidacies for multi-person elections in an alternate and sequential manner. For its part, article 94 states that within the candidates to be elected, equal participation between men and women must be guaranteed and the principles of parity, alternation, sequentially, etc., as well as equality in resources and opportunities of all candidates. Article 99 states that in the case of multi-person candidates, they must be presented in lists with main and alternate candidates, for which it emphasizes the fact that the lists are required to be made up equally with a sequence of women-men or men-women. until the total number of main and alternate candidates is completed, while article 163 establishes that the prefectures will be chosen by pairs made up of a man and a woman or vice versa. Therefore, the rule also states in article 165 that, in the case of ties between candidates of different genders, if a woman is among those tied, she will have preference in the award in application of the positive action measures and the principles of equity and parity that the Constitution and the law recognize, so that it occupies the designated seat.

On the other hand, article 105 establishes a power to control these forms of election, granted to the National Electoral Council and the Provincial Electoral Boards (2017) insofar as they can refuse the registration of candidacies if the lists do not strictly maintain equity, parity, alternation and sequentially between women and men. Also, in article 160 it is stated that the representatives of the National Assembly, representatives before the Andean Parliament, councilors and regional councilors, the district and municipal councilors and members of 
rural parish boards must be elected under these strict criteria of parity.

What was raised in advance, expresses how the legal structure of the norms in parliamentary matters in Ecuador is contextually designed, considering the establishment of these constitutionally backed laws as reflected by Balázs (2016), which come to refer to a process and not a goal in itself therefore, more than their successes or failures, it is necessary to identify what aspects and practices work, as well as what are the possible restrictions for a wider application. Consequently, it is necessary for those of us who subscribe to this article to carry out an in-depth analysis of what the statistics on the application of these measures show, in order to know the reality raised in terms of gender and legal conditions that govern women in Ecuador.

\section{Research Method}

The present study is based on a multi-method approach, where researchers are interested in beliefs, percentages, experiences and systems of meaning. The mixed or multi-method research includes statistical analysis and empirical calculation according to Brooks, Lainio, and Lažetić (2020). In this way, the roots of qualitative research are found in social and cultural anthropological, philosophical, psychological, historical and sociological research, contemplating a theoretical-legal documentary type design (Corona et al., 2017).

A concurrent transformative research design (DISTRAC), a model recommended by Hernández, Fernandez, and Baptista (2014), was consolidated into multi-method studies, where qualitative and quantitative data are collected at the same time, and analyzed in the same way without a paradigm having greater value or weight.

The research has a longitudinal non-experimental character as it is a legal and social study, that is, the qualitative paradigm responds to a design of ethnographic character whose scope of research is interpretative incorporating the description of the object of study. The quantitative paradigm, through a descriptive analysis of data obtained through percentage sources. All the methods studied in this research are from the theoretical level of knowledge with a systemic approach where phenomena are studied (law and society) in order to interpret the developed subject (Cajka, Amer, Ridenhour, and Allpress, 2018).

As an information analysis technique, data triangulation was applied, contrasting historical data, laws and legal reforms, theoretical bases and descriptive interpretations by the authors (Hyett, Kenny, and Dickson, 2014). The interpretative method facilitated a complex analysis of the data obtained from the primary sources. These sources are supported by the current organic laws of the Republic of Ecuador, gender equality contexts and humanistic philosophical bases.

The study also considers the theoretical contributions of various specialists in gender equality, as expressed by Navarro (2017), when he states that equality before the law is a true quest to establish the guarantee of identity. From a methodological perspective, the study focuses on three strategic dimensions for 
understanding the issue addressed in this article: first, constitutional regulation of gender equality in Ecuador; second, legal regulation of gender equality in Ecuador; and finally, actual data on women's parliamentary participation in Ecuador within the scope of the relevant electoral law. By virtue of the methodology proposed, and after an exhaustive review of theoretical and documentary sources, three emerging categories are structured that should be clarified in order to understand the issue addressed in this study: firstly, the Constitutional Regulation of Gender Equality in Ecuador; secondly, the relevant aspect of the Legal Regulation of Gender Equality in Ecuador; and finally, the role of society in the active participation of women in the political world of Ecuador.

\section{Results and Analysis}

The Ecuadorian State legally contemplates the participation of women in all these public and social spheres. As has been expressed, the legal norms that regulate electoral matters are quite strict regarding gender parity in compliance with the constitutional precepts that are also quite guaranteeing in the way. However, it is also pertinent to analyze the statistical figures that support the application of these legal norms and for them a brief introduction could be made regarding the world panorama in this matter.

In a first approximation, the current parliamentary representation of women has improved considerably compared to a decade ago, as recognized in the Report on the Millennium Development Goals in 2019 (ONU, 2019). points out that in parliamentary matters, women today represent $19 \%$, which means a greater number than they represented 4 years ago when the final report on the sustainable development goals was made, which results in 2019 participation $24 \%$ worldwide, which constitutes an increase of at least 5 points compared to 2010 in this parliamentary matter, but it should be noted that only in 15 countries, the parliamentary representation of women reaches $40 \%$ or more, which means that it directly influences whether they are considered for the corresponding decision making, a situation that has progressively increased in recent years but continues to be. It is proportionally low, due to the fact that only $27 \%$ of women in the world hold managerial positions, according to the same Report on the un Millennium Development Goals in 2019.

In order of ideas, it should be noted that in report of Centre for the Sustainable Development Goals for Latin America and the Caribbean (2020), the proportion of participation of women in these countries reaches at least 39\% in general. However, with regard to Ecuador, it is pertinent to state that, despite the foregoing, there was a significant increase in the participation of women in the electoral sphere, which implies that it is progressive, however, it is proportionally low. Despite legislative measures. This was recently indicated by the ONU (2019), when mentioning the above, it expresses that, despite the aforementioned legal norms, women have not achieved large representations for at least the last 5 years. In any case, the ONU (2019) according to its latest statistics in 
2019, women have reached a representation only in 4 prefectures $(17.39 \%)$ and 18 mayors (8.14\%), which represents a slight increase of the figure that was handled 5 years ago in the penultimate elections of this nature where they obtained 2 prefectures (8.7\%) and 16 mayors (7.24\%) as shown in Figure 1.

Analyzed, the approach explained by the same organization would have to be used, where it is pointed out that one of the reasons why women do not actively participate in political life is gender violence. According to the latest study carried out by the ONU (2019) on political violence, two thirds of women (66\%) identify psychological violence as the most frequent. The same organization recognizes that in the social spheres of Ecuador there are smear campaigns, rumors against these women and the factor of invisibility is also present, which responds not only to a low dissemination of the candidacy or public management, but to other more sensitive factors that according to the ONU (2019) may be isolation, exclusion or marginalization, from the party, in local government or in the community. Based on the report on gender inequality in the political participation of women in Latin America and the Centre for the Sustainable Development Goals for Latin America and the Caribbean (2020), which establishes the multiple causes that perpetuate inequality between men and women, it is precisely the validity of an origin of Patriarchal gender, in addition to poverty as a multidimensional condition that notably affects women, the legal reform processes in the States that carry with them an institutional fragility that affects the legal labor order of women, in addition to the mechanisms of each State for gender equality without adequate and sufficient support from government entities among others. In light of the above, the analysis of who are the main actors who exercise such political gender violence raises results that are not very encouraging.

Consequently, the same organization recognizes that in the countries $58 \%$ are represented by leaders of political parties, electoral candidates, activists of political parties and electoral campaign personnel, recognizing the ONU (2019) the social factor that determines visibility of women, observing likewise that there is also a percentage that reaches $32 \%$ corresponding to social actors, that is, voters, family members, community members or groups, the media and social networks

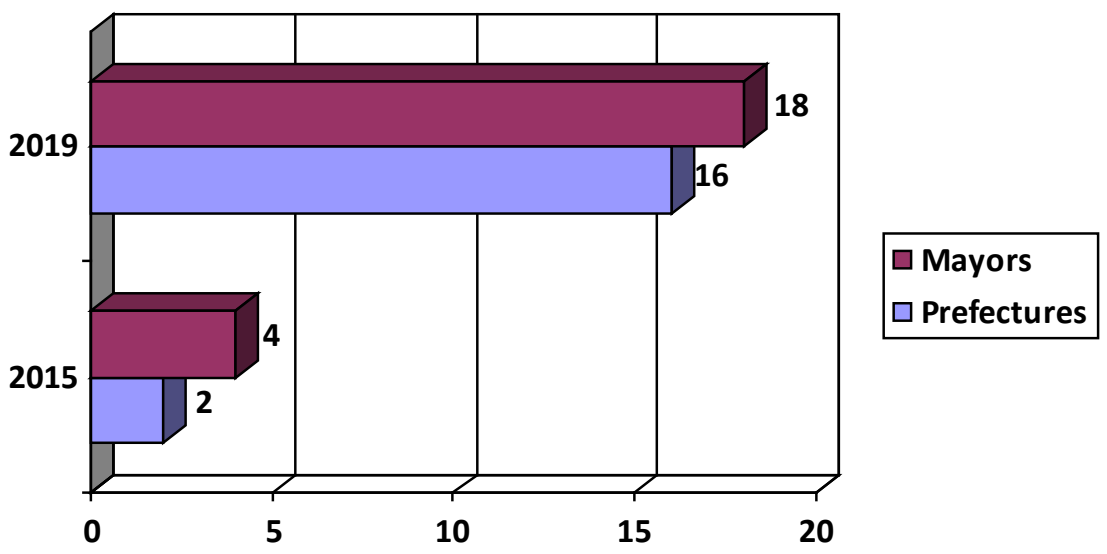

Figure 1. Example representation of women in Ecuador's 2019 Elections. 
that contribute to the loss of prestige of women Within the political sphere of Ecuador, therefore, the inclusion of women in politics implies by itself the guarantee of being elected in positions that come from an election or positions that are appointed, however, the inclusion is not enough anymore that in addition to inclusion there must be representation, understood as the behavior of the women elected in representation of the interests and needs cities of the women's collective.

Therefore, if it is possible to stand out based on the statistics that it is maintained to little benefit for women, in this way it can have a social aspect rather than a legal aspect since the members of Ecuadorian society intend to maintain entrenched gender stereotypes that they do not allow the normal development of the principles of this study. This is stated by Latorre (2017) and Guzñay (2018) who point out that inequality is established and rooted in Ecuadorian society from all possible nuances, but with greater force within the most important, such as, for example, in the field electoral that is the central axis of this study. The authors point out that, in fact, the low eligibility of women in Ecuador is due more to the legal norms that require the participation of the female group in these processes than to the will of the Ecuadorian society to elect them. The latter is linked to what was established by Quinatoa (2015) who, when making a historical review of this issue in Ecuador, established that even in that country's history, although it is not possible to differentiate with certainty who was in charge in the most prehistoric societies (whether men or women), there has always been a marked division between male and female activities, with sex clearly considered as a determining factor in the development of these activities. This factor, which seems to be isolated in reality, for the authors of this research, is rather a determining factor in the marked social stereotypes of Ecuador.

For the purpose of establishing the conclusions, reference is made to Ecuador's legal norms that have established a parity system in favour of women to guarantee their participation within the country's parliamentary spheres. The applications of these norms are reflected in the representation that women currently have in Ecuador's social, legal and parliamentary spheres, which corresponds to a number in Latin America that is 39 percent, as previously stated this percentage is still disproportionately low in relation to male participation in parliamentary spheres. It should be noted that, despite the parity rules that promote women's candidacies, the current data only reaches a proportion of 4 prefectures and 18 mayoralties at the national level (Ecuador), which translates into a minimum increase of only 2 points over the data from the elections that take place in Ecuador every four years for the parliament.

This means that legislative measures have not succeeded in achieving gender parity in Ecuador and have been subordinate only to the number of candidates in the country, since women's elections continue to have low margins in relation to men's, as indicated in the reports we have studied, owing to culturally widespread social factors that prevent women from being elected to these parliamentary posts and, in turn, since they are not elected, their active participation in the 
spheres of power is compromised, which prevents the achievement of gender equality in Ecuador in parliamentary matters.

In summary, it can be noted that government policies significantly improve women's rights. But compared to other countries in Latin America, the rates of female participation are lower. Similarly, in Ecuador, there are social groups that generate disrepute against these women as a model of macho society.

\section{Conclusion}

Finally, it can be concluded that women play a preponderant role, as well as the relevant data on the subject of the study and other issues addressed in the development of the research, it is clear that the normative evolution of Ecuador does not correspond to social evolution. These social, legal and parliamentary factors are currently isolated and prevent the gradual achievement of true gender equality for women in Ecuador. Finally, the researchers can conclude that the role of women is not well balanced in the social, legal and parliamentary spheres, Both in its legal, political, public, social, carrying out international agreements of ONU (2019), OTOAD (2010), and Lopez, De le Court, \& Canalda (2014) the results and/or practice of incorporating women in legal and parliamentary plans is not entirely compatible with these agreements.

The commitment of the signatories of this study is to continue providing prevention measures, such as the incorporation of women into government strategic plans, the eradication of gender violence and its shortcomings, measures and initiatives for equality that establish significant improvements in this field, since the response lies in education and the empowerment of women. Only through the effective preparation of social actors can the public policies that have been put in place to guarantee affirmative action measures in favour of women have greater force. A more educated society is a more inclusive society, and by being more inclusive, the modern precepts included in the rules will be taken into account in order to eradicate forms of discrimination.

\section{Conflicts of Interest}

The authors declare no conflicts of interest regarding the publication of this paper.

\section{References}

Balázs, B. (2016). From Liberal Democracy to Illiberalism. New Authoritarian Regimes, Hungarian Illiberalism and the Crisis of "Real Existing Liberalism". Revista Studia Política, 16, 409-429. http://www.studiapolitica.eu/Archive/2016/studia-politica-vol-xvi-no-3-2016

Brooks, R., Lainio, A., \& Lažetić, P. (2020). Utilizando métodos creativos para investigar a través de la diferencia. Una introducción al número especial. International Journal of Social Research Methodology, 23, 1-6. https://doi.org/10.1080/13645579.2019.1672281

Cajka, J., Amer, S., Ridenhour, J., \& Allpress, J. (2018). Geo-Sampling in Developing Nations. International Journal of Social Research Methodology, 2, 729-746. 
https://doi.org/10.1080/13645579.2018.1484989

Centre for the Sustainable Development Goals for Latin America and the Caribbean (2020). ODS 2019 Index for Latin America and the Caribbean. Centre for Sustainable Development Goals for Latin America and the Caribbean: Bogotá, Colombia. https://s3.amazonaws.com/sustainabledevelopment.report/2019/2019_lac_sdg_index.p df

Corona, A., Álvarez, G., Romero, A., Castro, Vega, V., Comas, R., \& Velázquez, M. (2017). Scientific Research and Forms of Qualification: Conceptual and Practical Aspects. Quito: Editorial Jurídica del Ecuador.

Council of Europe (1999). Details of Treaty No. 173. Criminal Law Convention on Corruption. https://www.coe.int/en/web/conventions/full-list/-/conventions/treaty/173

Constitución de la República del Ecuador, CRE (2008). Asamblea Nacional de la Republica del Ecuador.

https://www.asambleanacional.gob.ec/sites/default/files/documents/old/constitucion_d e_bolsillo.pdf

Daniely, D., \& Lederman, S. (2019). Gendered Cultural Differences and Change in Gender Roles among Displaced Refugees. Indian Journal of Gender Studies, 26, 364-384. https://doi.org/10.1177/0971521519861177

Guzñay, J. (2018). Las mujeres en un país plurinacional e intercultural, Ecuador. Revista de estudios de género: La ventana, 6, 358-389. https://doi.org/10.32870/lv.v6i48.6733

Hernández, R., Fernández, C., \& Baptista, L. (2014). Metodología de la Investigación. México: Editorial Trillas.

Hook, G., \& Wolfe, M. (2018). Affective Violence: Re/Negotiating Gendered-Feminism within New Materialism. Journal of Gender Studies, 27, 871-880.

Huh, R. K. (2020). Revisiting Feminist Care Ethics for the Age of the "Pluralistic Family". Asian Journal of Women's Studies, 26, 22-35.

https://doi.org/10.1080/12259276.2020.1718365

Hyett, N., Kenny, A., \& Dickson, V. (2014). Methodology or Method? A Critical Review of Qualitative Case Study Reports. International Journal of Qualitative Studies on Health and Well-Being, 9, Article No. 23606. https://doi.org/10.3402/qhw.v9.23606

International Labour Organization, ILO (2016). Direct Request (CEACR)-Adopted 2015, Published 105th ILC Session (2016). Discrimination (Employment and Occupation) Convention, 1958 (No. 111)_Ecuador (Ratification: 1962).

http://www.ilo.org/dyn/normlex/en/f?p=NORMLEXPUB:13100:0::NO::P13100_COM MENT_ID:3253474

Latorre, S. (2017). El derecho a la Igualdad, conceptos y percepción en Chile. Centro de democracia y comunidad. https://www.cdc.cl/web/wp-content/uploads/2018/03/RyD-N\%C2\%B017.pdf

López, J., De le Court, A., \& Canalda, S. (2014). Breaking the Equilibrium between Flexibility and Security: Flexiprecarity as the Spanish Version of the Model. European Labour Law Journal, 5, 19-43. https://doi.org/10.1177/201395251400500104

Navarro, M. (2017). La Igualdad De Género Como Derecho Humano: Un Análisis Desde La Perspectiva Del Derecho Internacional En El Ámbito Laboral. Quito: Editorial Jurídica del Ecuador.

ONU (2015). The Millennium Development Goals Report 2015. IME for Global Action for People and Planet.

https://www.un.org/millenniumgoals/2015_MDG_Report/pdf/MDG\%202015\%20rev\% 20(July\%201).pdf 
ONU (2019). The Millennium Development Goals Report 2019. Sustainable Development Goals Report 2019.

https://unstats.un.org/sdgs/report/2019/The-Sustainable-Development-Goals-Report-2 019.pdf

Orbegoso, M. (2016). La Igualdad Material como Fin del Estado Social. Revista de Estudiantes Ita Ius Esto, 1, 1-10.

Organic Code of Territorial Organisation, Autonomy and Decentralisation, OTOAD (2010). Función ejecutiva de la presidencia de la república del Ecuador. Código orgánico de organización territorial, autonomía y descentralización.

https://urbanlex.unhabitat.org/sites/default/files/codigo_organico_de_organizacion_ter ritorial_autonomiautf-8q_y_descentraliz.pdf

Organic Law on Electoral and Political Organizations (2009). Official Register Supplement 578 of 27-Apr-2009. National Assembly Legislative and Audit Commission Office No. SCLF-2009-172.

Pons, E. (2015). Igualdad y no Discriminación por Razón de Sexo: Nociones Jurídicas Básicas en AA. VV: Análisis Feminista del Derecho: Teorías, igualdad interculturalidad y violencia de género. Barcelona: Publicaciones de la Universidad de Barcelona.

Provincial Electoral Boards (2017). Election Results 2017. National Electoral Council.

Quinatoa, E. (2015). Estudio Introductorio en AAVV: Historia de Mujeres e Historia de Género en el Ecuador. Ecuador: Editorial IPANC.

Vela, R. (2009). Programa de inserción socio laboral para mujeres víctimas de violencia de género en AA. VV: Mujeres Inmigrantes en Andalucía. España: Publicaciones Literalia. 